BOJAN BEŠKOVNIK, Ph.D. ${ }^{1}$

(Corresponding author)

E-mail: bojan.beskovnik@fpp.uni-lj.si

ELEN TWRDY, Ph.D. ${ }^{1}$

E-mail: elen.twrdy@fpp.uni-lj.si

SANJA BAUK, Ph.D. ${ }^{2,3}$

E-mail: bsanjaster@gmail.com

${ }^{1}$ Faculty of Maritime Studies and Transport

University of Ljubljana

Pot pomorščakov 4, 6320 Portorož, Slovenia

2 Maritime Faculty Kotor

University of Montenegro

Dobrota 36, 85330 Kotor, Montenegro

${ }^{3}$ Faculty of Applied Sciences

Durban University of Technology

Steve Bico Campus, 4001 Durban, South Africa
Traffic Management Original Scientific Paper

Submitted: 26 Feb. 2018

Accepted: 7 Feb. 2019

\title{
DEVELOPING HIGHER BERTH PRODUCTIVITY: COMPARISON OF EASTERN ADRIATIC CONTAINER TERMINALS
}

\begin{abstract}
This paper analyses changes of berth infrastructure and suprastructure by global container terminals (CTs) and by four eastern Adriatic ports in the last decade. The emphasis is on understanding whether CTs at Koper, Trieste, Rijeka and Bar achieved higher berth utilisation and productivity per ship-to-shore (STS) crane and if so, how and whether their development is in line with the global trend in CT berth productivity. On this basis a comparison model of twenty selected global CTs is used for productivity comparison as a first step in the process of analysing subsystem productivity. The study shows that four eastern Adriatic ports made different decisions, but with the same goals in reaction to the increased flow of containers via the Adriatic Sea transport route. Their main goal was to increase berth productivity by controlling the eventual subsystem overcapacity. According to observations, the Port of Koper is running at the subsystem's upper level, while CTs in Trieste, Rijeka and Bar operate with certain degree of berth infrastructural, and suprastructural overcapacity.
\end{abstract}

\section{KEY WORDS}

container terminal; berth; infrastructure; productivity; eastern Adriatic;

\section{INTRODUCTION}

Container terminals (CTs) are very dynamic systems that are constantly under strong pressure from technical and technological developments of the entire transport sector. This development is especially driven by global economic development and the financial pressure of container carriers as key stakeholders in the container industry. On this basis, bigger container ships are used on main maritime routes, creating infrastructural and suprastructural pressure on all terminal subsystems. The berth subsystem is usually one of the main bottlenecks in accepting increasing flows of containers when container carriers introduce bigger ships [1]. Terminal operators are forced to adapt berth infrastructure by deepening the berth basin and extending the berth length. From the suprastructural point of view, they have to invest in new shipto-shore (STS) cranes with longer outreach and higher lift height. Such STS cranes also provide faster hoisting and trolley speed.

The global container port throughput reached 699 million TEU - 1,720 million tons of cargo transported by container ships - in 2016 [2]. Although the throughput did not increase significantly in the last three years (on average $+2.9 \%$ yearly), the past ten years show significant development of global container volume. The world container port throughput increased by $57.8 \%$ in the last decade, supported partly by larger ships. While the largest group of container ships by capacity was between 5,000 to 7,500 TEU a decade ago, nowadays this has changed to a group of ships from 7,500 to 10,000 TEU capacity. With new orders of container ships above 10,000 TEU, up to 22,000 TEU, the container fleet will change drastically in the next five to ten years; $80 \%$ of new orders by capacity are for container ships with over 10,000 TEU [3]. CTs will be under additional pressure to enhance and modernize their infrastructure and suprastructure.

This development of the global container industry influenced the development of the container market and CTs in the eastern Adriatic (EA) as well, of course. The three northern Adriatic (NA) ports - Koper, Trieste and Rijeka - operate very close to each other, meanwhile the Port of Bar being more distant, but they compete for the same hinterland markets [4]. 
Although they are market competitors, they all achieved significant increase of yearly throughput. All together they handled almost 1 million TEU more in 2016, compared to the volume of containers handled in 2006. All four ports made investments and operational improvements in their berth subsystems. The throughput increased significantly and we can predict that although new capacity was installed the utilization of infrastructure and berth productivity increased according to the results of 2006 .

The aim of the study is to analyse EA terminals development and consequently berth utilization that is attracting new direct and feeder container services and new container flows for an expanded hinterland market. The study includes the analysis and development comparison of twenty global CTs in the last ten years, to understand better the past and actual position and efficiency of EA CTs. The data comparison model supports better understanding whether CTs at Koper (Luka Koper), Trieste (Trieste Marine Terminal), Rijeka (Adriatic Gate Container Terminal) and Bar (Port of Adria) have margins for actual subsystems optimisation or they operate at a level that calls for new infrastructural upgrades and suprastructural installations.

\section{THEORETICAL BASIS OF RESEARCH}

Maritime CTs organize their work in three main subsystems: berth subsystem, storage subsystem and inland handling subsystem. From the hierarchical point of view, the berth represents the basic subsystem, with the following specific characteristics:

- It accommodates transport means (ships) with higher daily operational costs, compared to other transport means entering and exiting the system;

- It needs higher investments for modernization and consequently covers higher amortization rate,

- It attracts new container carriers in establishing new liner connections,

- It is directly dependent on dynamically changing ship size and capacity.

All of these characteristics represent the basis for a continuous upgrade of the subsystem. Sys et al. [5] expose the connection between ship size and terminal operation as a key element in securing positive economic results. Container carriers choose terminals based on their productivity and, consequently, shorter stay in the port. At the same time, they introduce bigger ships, with more than double capacity than a decade ago. Such ship daily operational costs are also double; carriers and terminal operators follow the same goal of a ship minimal stay in the system. Kim and Lee [6] highlight that very often such requests are included in commercial agreements, between carriers and terminal operators.
Terminal operators follow carriers' and trade's expectations by new investments in berth extension, additional berth positions, deeper berths and new STS cranes. Such modernisation requires greater funds and brings along the risk of eventual overcapacity in the longer term, which can lead to financial difficulties. $\mathrm{Ho}$ and $\mathrm{Ho}$ [7] exposed the risk of high investment in the port infrastructure and discussed how to manage different developing scenarios to minimise business risks. Koh [8] exposed the need for optimum container port capacity development, where investments must be in correlation with the near future container traffic movements, and Novaes et al. [9] highlighted the problem of berth capacity expansion and demand volatility. Management must find an approach to plan and install excess capacity, with an orientation towards a limited time of overcapacity.

Different researchers propose optimisation strategies by using algorithms for quay crane scheduling process (QCSP) and berth allocation process (BAP) [1, $10,11,12,13,14]$. These are mathematical tools for in-depth analyses of system performance. Li et al. [15] exposed methods for higher optimisation based on infrastructural data, as key variables in the optimisation process. Stojaković and Twrdy [16] elaborated a DST (Decision Support Tool) for faster and simplified analyses of berth capacity. Moreover, Bassan [17] proposed analysing berth subsystem infrastructure and suprastructure utilization through berth length comparison and STS crane utilization and productivity. Anyhow, with a simplified data comparison model, where productivity data are compared between similar terminals, a macro view of berth productivity can be elaborated. It can be defined as the first stage process for the later in-depth productivity research of any defined limiting factor.

\section{METHODOLOGY}

The focus of the study is on berth development by four main EA ports that compete for almost the same hinterland market. All four CTs made important changes in terminal structure and berth adjustments over the last ten years. Due to a very strong increase in container trade, primarily from Asia through the South-European transport route, it is important to understand whether the berth subsystems of all four terminals are developing their infrastructure and suprasturucture in line with global trends. Moreover, it is important to understand the levels of utilization and productivity compared with global container terminals for future effective development as well. On this basis, a study of the last ten years of development at twenty global CTs has been elaborated. The output of analysed data serve as a comparison model to better understand berth utilization and productivity at four EA container terminals. 
The study consists of three main research hypotheses, which contain assumptions that:

- Global CTs follow container trade expansion by berth infrastructure and suprastructure modernisation, influencing the increase in berth utilization and productivity;

- Eastern Adriatic CTs follow the global trend in berth modernisation and achieve higher subsystem utilization and productivity, compared to results a decade ago;

- Eastern Adriatic CTs have possibilities for berth utilization and productivity improvement without further investments in berth infrastructure and suprastructure.

A comparison model includes twenty global CTs divided into four groups by yearly throughput achieved in 2006. The first group includes five terminals with yearly throughput of up to 450,000 TEU and the second group includes five terminals with yearly throughput between 450,000 and 850,000 TEU. The third group contains terminals from 850,000 to $1,250,000$ TEU and the fourth one, terminals with throughput over 1.25 million TEU yearly. Terminals from different regions are used in the comparison model, because different managing philosophies and technological cognitions influence the terminal performance. Consequently, a wider perspective for EA ports' analysis is available.

Data regarding yearly throughput at the berth subsystem, about berth length and the number of specialized container STS cranes are used as key variables. A comparison between the situations in 2006 and 2016 on all selected global CTs is made in order to understand where and how the terminals have followed an increase in the global container trade. Finally, these data are compared to past and present situations at the berth subsystems of the four EA CTs.

\section{BERTH SUBSYSTEM DEVELOPMENT AND PRODUCTIVITY}

Comparison of the development of the berth subsystem and the achieved productivity are based on horizontal comparison by comparing data from 2006 and 2016, and in vertical way, by comparing data with the same group of terminals. For the measured productivity, the basic performance indicators of the berth subsystem are used, namely TEU per berth length, TEU per STS crane and TEU per working hour of each crane. The number of TEUs per crane working hour considers 360 days of working timetable and 24 hours of working time at the berth subsystem.

By comparing the change in the number of STS cranes and the length of the berth and changing the volume of container throughput, changes in performance indicators are calculated. Due to the different investment policies of ports and their container terminals, there are different starting points for optimisation of technological processes. The obtained results of productivity comparison of EA terminals with Group average value give answers to three main research hypotheses.

\subsection{Berth productivity of four analysed groups of CTs and EA CTs in 2006}

The first group of CTs consists of terminals in Ravenna - TCR, Aqaba, Buenos Aires, Varna and Lisbon. These terminals achieved a yearly throughput between 100,000 TEU and 392,000 TEU in 2006. In the second group are terminals from Livorno, Nabeta, Cagliari, Tobishima and Thessaloniki. The average yearly throughput of these five terminals in 2006 was 593,300 TEU. The third group includes container terminals from Dammam (HPH), La Spezia, Surabaya, Mumbai and Xiamen (HPH). Their average throughput in 2006 was 981,240 TEU. In the last group are mega CTs from Freeport, Piraeus, Ningbo (HPH), Panama and Gioia Tauro, with an average yearly throughput of 1,826,740 TEU in 2006.

The first group of CTs had on average four STS cranes and a berth length of $615 \mathrm{~m}$. The second group used almost double the berth length, as the average group length was $1,105 \mathrm{~m}$. At these berths on average 6.4 STS cranes were used. The third group of terminals, with throughput from 850,000 to 1.25 million TEU, used on average 1,085 metres of berth length and were equipped with ten STS cranes. The last group had a significantly longer berth length (on average 1,866 $\mathrm{m}$ ) and handled containers with 13.6 STS cranes.

The analysis of berth productivity per each group shows that terminals with lower yearly throughput achieve lower productivity. Namely, the first group of terminals moved 392.26 TEU per metre of berth length and 58,247 TEU per STS crane. On average, 6.74 TEU per hour were handled by each STS crane (see Figure 1). The second group of CTs moved 614.15 TEU per metre of berth length and 102,178 TEU per STS crane. The average value stands at 11.83 TEU handled per working hour by each STS crane. The third group achieved a throughput of 998 TEU per metre of berth length and 11.54 TEU per STS crane hour. The fourth group of terminals achieved evidently higher productivity, with 1,120 TEU per metre of berth and 15.89 TEU per crane hour.

As presented in Table 1, the four EA terminals handled on average 137,969 TEU in 2006, with strong negative impact of the Port of Bar. This CT handled just 17,854 TEU or over ten times less compared to the Koper and Trieste terminals. The container terminal in Trieste had the leading role among the four analysed CTs. The terminal used 1,420 metre of berth length and operated with seven STS cranes. Although the terminal had a very large berth infrastructure and 


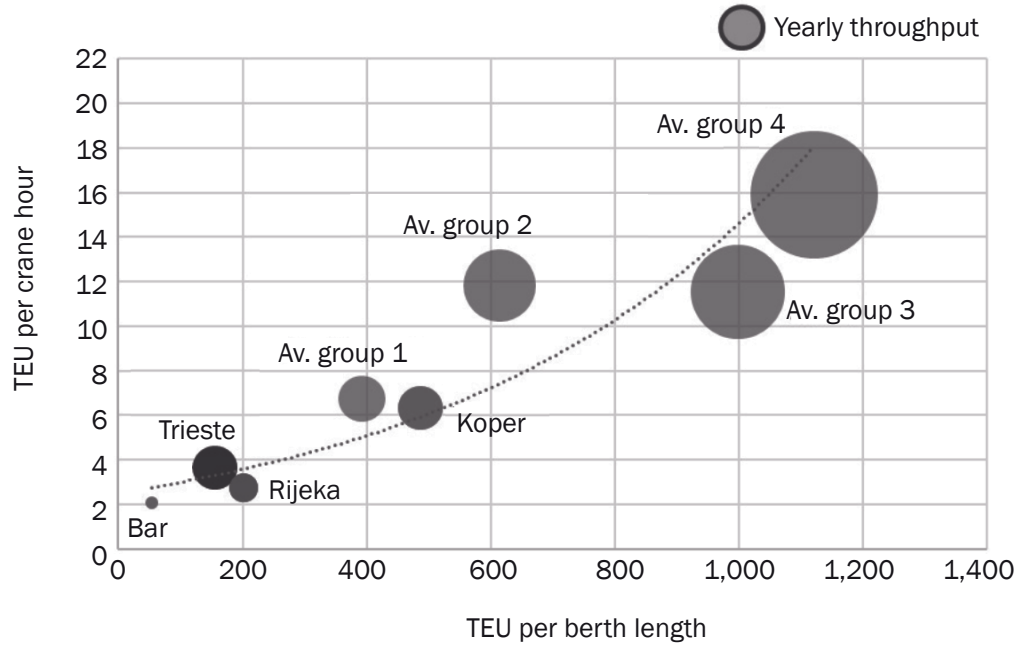

Figure 1 - Productivity in relation with yearly throughput at berth subsystem in 2006

Table 1 - Productivity of berth subsystem at Koper, Trieste, Rijeka and Bar CT in 2006

\begin{tabular}{||l|c|c|c|c|c|c||}
\hline \hline Terminal & Throughput (TEU) & No. STS cranes & Berth length [m] & TEU/berth length & TEU/crane & TEU/crane hour \\
\hline \hline Koper & 218,970 & 4 & 450 & 486.60 & $54,742.5$ & 6.34 \\
\hline Trieste & 220,661 & 7 & 1,420 & 155.40 & $31,523.0$ & 3.65 \\
\hline Rijeka & 94,390 & 4 & 469 & 201.26 & $23,597.5$ & 2.73 \\
\hline Bar & 17,854 & 1 & 330 & 54,10 & $17,854.0$ & 2.07 \\
\hline
\end{tabular}

Source: Ports web sites and annual reports for 2006 [18, 19, 20]

suprastructure used by terminals with a yearly throughput of up to $850,000 \mathrm{TEU}$, the difference in the yearly throughput compared to the Koper CT was minimal.

Compared with the average results obtained by the first group of container terminals only the Port of Koper achieved satisfactory results, with 6.34 TEU movements per STS crane hour and 486.60 TEU per metre of berth length. The container terminal in Rijeka handled 94,390 TEU, with four STS cranes and 469 metre of berth length in 2006 [20], representing almost the same installed capacity as at the Koper terminal, but with a significant difference in berth utilization and productivity. The terminal berth productivity at Koper, compared to the first and second group of terminal performance, shows that it was undoubtedly necessary to invest in infrastructure and suprastructure upgrade. At the same time, the terminals in Bar, Rijeka and Trieste had significant berth overcapacity. This is especially true for the CT in Bar, as the berth infrastructure utilization was just 54.10 TEU per berth length. Due to just one installed crane and with yearly throughput of 17,854 TEU the crane productivity per hour was $25 \%$ lower compared to the Rijeka CT crane performance.

\subsection{Berth development and productivity of four groups of CTs until 2016}

The global container trade has increased significantly over the last decade. From 443 million TEU of global port throughput in 2006 , the trade increased to
699 million TEU in 2016, an increase of $57.8 \%$ or on average $5.8 \%$ on a yearly basis. At the same time, the four EA CTs achieved significantly growth. All four terminals together handled 551,875 TEU in 2006, meanwhile their yearly throughput surpassed 1.51 million TEU in 2016 , an increase of $274 \%$ or $27.4 \%$ yearly.

The 20 analysed global CTs moved 18.21 million TEU in 2006 and 25.94 million TEU in 2016. This represents an increase of $43 \%$ and is in line with global container trade growth. CTs from the first group expanded the berth length to 806 metres and invested in one additional STS crane on average. The average yearly throughput increased to 304,066 TEU, a $26.6 \%$ increase. The increase in throughput did not follow the installed new capacity at the berth subsystem, because terminals achieved lower productivity, with 355 TEU per metre of berth length and 6.63 TEU per STS crane hour on average. The second group of observed terminals also invested in berth extension and additional STS cranes. The terminals have increased their yearly throughput by just $16.7 \%$ on average in the last ten years. The installed berth capacity increased by $20 \%$ during the same time. Consequently, the average terminal productivity per crane decreased to 10.91 TEU per crane hour, while berth utilization remained at the same level of 622 TEU per berth length.

On the other hand, terminals from the third and fourth group saw important increase in the yearly throughput. They also invested in berth extension and 
additional STS cranes. Considering the same grouping basis that uses the throughput from 2006, the analysed terminals from the third group increased the yearly throughput to an average value of 1.34 million TEU. These CTs moved on average 14.28 TEU per crane hour and 1,254 TEU per metre of berth length. It has to be highlighted that the Mumbai (APM), Surabaya and La Spezia terminals increased their yearly throughputs to $1.79,1.40$ and 1.27 million TEU, respectively: thus, these three systems work on a level that is typical for CTs with yearly throughput of over 1.25 million TEU. By inserting them into the fourth group of analysed terminals the following data are typical for the third and fourth groups of terminals presently:

- $3^{\text {rd }}$ Group: terminals have on average 11 STS cranes, and 1,148 metre of berth length. They achieve 1,094 TEU movements per berth length on average and 12.82 TEU per crane hour.

- $4^{\text {th }}$ Group (Freeport, Piraeus, Gioia Tauro, Panama-Balboa, Ningbo Beilun T., Surabaya, Mumbai - APM and La Spezia): use on average 16.75 STS cranes per terminal and 1,726 metre of berth length. Their berth utilization and crane productivity are significantly higher when compared to smaller terminals, because they move on average 15.56 TEU per crane hour and 1,396 TEU per metre of berth length in use.

The analysis confirms that global CTs follow global container trade development. They invest in berth subsystem adjustments according to carrier's expectations to accommodate bigger ships that request longer berths and more STS cranes (super-post-panamax cranes - SPPC or mega-max cranes - MMC), with longer outreach and faster hoisting speed. All together 20 CTs have installed 30\% more STS cranes compared to the number of STS cranes in use in 2006. In addition, they extended their berths by additional $13 \%$ on average.

\subsection{Development of eastern Adriatic terminals and performance comparison}

The four EA CTs at Koper, Trieste, Rijeka and Bar have increased their throughput significantly over the global container port throughput that stands at $57.8 \%$ over the last ten years. The Port of Koper moved 844,776 TEU in 2016. The yearly throughput increased by $285.8 \%$, or on average $28.6 \%$ per year. The container terminal at Trieste handled 449,491 TEU in 2016 and with this the terminal increased the yearly throughput by $103.7 \%$ over 2006 throughput. The Port of Rijeka achieved almost the same throughput increase in the last decade. With 177,401 TEU moved at the berth subsystem in 2016, this container terminal achieved an increase of $87.9 \%$. The CT at Bar also increased its throughput to 42,000 TEU in 2016; an increase of $135.24 \%$ from 2006.

As shown in Figure 2, the Port of Koper installed additional four STS cranes and modernized the old ones. At the same time the berth subsystem was extended by an additional $146 \mathrm{~m}$. Due to the very high increase

Table 2 - Productivity of berth subsystem at Koper, Trieste, Rijeka and Bar CT in 2016

\begin{tabular}{||l|c|c|c|c|c|c||}
\hline \hline Terminal & Throughput (TEU) & No. STS cranes & Berth length [m] & TEU/berth length & TEU/crane & TEU/crane hour \\
\hline \hline Koper & 844,776 & 8 & 596 & $1,417.41$ & $105,597.00$ & 12.22 \\
\hline Trieste & 449,491 & 7 & 770 & 583.75 & $64,213.00$ & 7.43 \\
\hline Rijeka & 177,401 & 4 & 628 & 282.49 & $44,350.25$ & 5.13 \\
\hline Bar & 42,000 & 1 & 330 & 127.27 & $42,000.00$ & 4.86 \\
\hline
\end{tabular}

Source: Ports web sites and annual reports for 2016 [19, 21, 22]

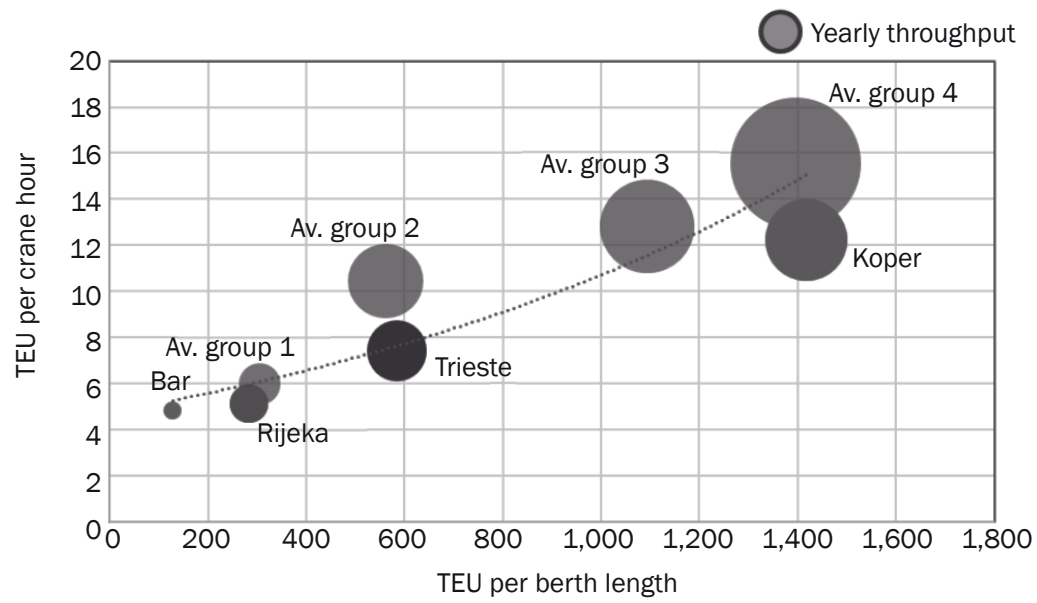

Figure 2 - Berth length and number of STS cranes used by four EA ports in 2016 
in the yearly throughput the berth utilization and productivity increased significantly. The CT handled 1,417.41 TEU per metre of berth length and 105,597 TEU per STS crane. The utilization of STS cranes more than doubled. Productivity per STS crane shows a very high result of 12.22 TEU per crane hour, ranking the terminal at the level of the biggest CTs in the world.

The container terminal in Rijeka also extended its berths and completely modernised and redesigned the technology of handling containers at the terminal. The western berth was closed and with berth extension, two berths are in use for a total length of $628 \mathrm{~m}$. This terminal handled 282.49 TEU per metre of berth length and 5.13 TEU per crane hour in 2016.

The CT at Bar did not make any changes to the berth infrastructure and suprastructure. On the contrary, the Trieste terminal reduced the berth length to $770 \mathrm{~m}$. The berth on the western side was closed and this area is now used for handling containers on rail. The terminal retained the same number of STS cranes, but they were modernised and an SPPC was added. The Trieste container terminal thus significantly increased berth utilization and productivity. With 583.75 TEU moved per metre of berth length an increase of almost three times was achieved; meanwhile, with 7.43 TEU movements per crane hour the productivity is more than double that of 2006 (see Table 3).

According to a comparison model of CTs and by achieved yearly throughput in 2016 , EA container terminals are divided into three different groups. The Rijeka and Bar CTs remain in the first group of terminals, Trieste is on the border between the $1^{\text {st }}$ and $2^{\text {nd }}$ group, while Koper is very close to the $3^{\text {rd }}$ group of terminals. The comparison with the selected 20 CTs performance presented in Figure 3 and Table 4 shows that:

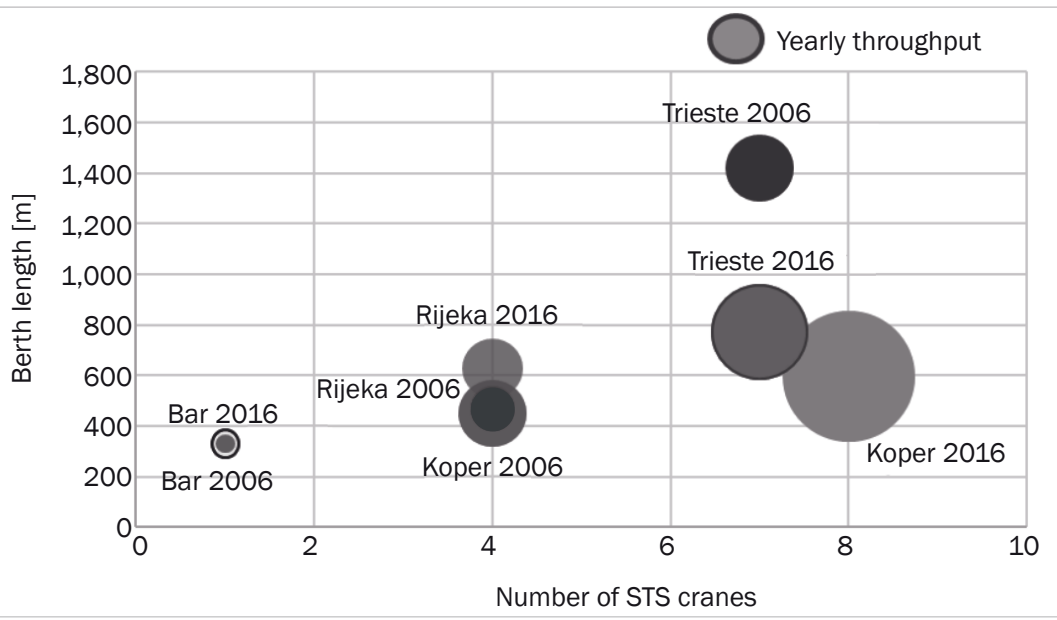

Figure 3 - Productivity in relation with yearly throughput at berth subsystem in 2016

Table 3 - Productivity increase of berth subsystem by Koper, Trieste, Rijeka and Bar CT in years 2006 and 2016

\begin{tabular}{||l|c|c|c|c|c|c||}
\hline Terminal & $\begin{array}{c}\text { Throughput } \\
\text { change (TEU) }\end{array}$ & $\begin{array}{c}\text { Change of no. } \\
\text { of STS cranes }\end{array}$ & $\begin{array}{c}\text { Change in berth } \\
\text { length [m] }\end{array}$ & $\begin{array}{c}\text { Change TEU/ } \\
\text { berth length [\%] }\end{array}$ & $\begin{array}{c}\text { Change in TEU/ } \\
\text { Crane [\%] }\end{array}$ & $\begin{array}{c}\text { Change in TEU/ } \\
\text { crane hour [\%] }\end{array}$ \\
\hline \hline Koper & $+625,806$ & +4 & +146 & +191.29 & +92.90 & +92.90 \\
\hline Trieste & $+228,830$ & 0 & -650 & +275.66 & +103.70 & +103.70 \\
\hline Rijeka & $+83,011$ & 0 & +159 & +40.36 & +87.94 & +87.94 \\
\hline Bar & $+24,146$ & 0 & 0 & +135.24 & +35.24 & +35.24 \\
\hline
\end{tabular}

Table 4 - Productivity comparison of EA terminals with Group average value in 2016

\begin{tabular}{|l|c|c|c|c|c|c|c|c||}
\hline \multirow{2}{*}{} & \multicolumn{2}{|c|}{ Av. Group 1 } & \multicolumn{2}{c|}{ Av. Group 2 } & \multicolumn{2}{c|}{ Av. Group 3 } & \multicolumn{2}{c|}{ Av. Group 4 } \\
\cline { 2 - 10 } & $\begin{array}{c}\text { TEU/berth } \\
\text { length }\end{array}$ & $\begin{array}{c}\text { TEU per } \\
\text { STS/h }\end{array}$ & $\begin{array}{c}\text { TEU/berth } \\
\text { length }\end{array}$ & $\begin{array}{c}\text { TEU per } \\
\text { STS/h }\end{array}$ & $\begin{array}{c}\text { TEU/berth } \\
\text { length }\end{array}$ & $\begin{array}{c}\text { TEU per } \\
\text { STS/h }\end{array}$ & $\begin{array}{c}\text { TEU/berth } \\
\text { length }\end{array}$ & $\begin{array}{c}\text { TEU per } \\
\text { STS/h }\end{array}$ \\
\hline \hline Koper & $1,112.36$ & 6.21 & 856.79 & 1.77 & 323.68 & -0.60 & 21.38 & -3.34 \\
\hline Trieste & 278.70 & 1.42 & 23.14 & -3.02 & -509.97 & -5.39 & -812.28 & -8.13 \\
\hline Rijeka & -22.57 & -0.87 & -278.13 & -5.32 & -811.24 & -7.68 & $-1,113.55$ & -10.43 \\
\hline Bar & -177.35 & -1.15 & -432.92 & -5.59 & -966.03 & -7.96 & $-1,268.33$ & -10.70 \\
\hline
\end{tabular}


- CTs at Bar and Rijeka operate below average results of CT from the first group and consequently other groups;

- Trieste CT operates with significantly better berth utilization compared to the first group average value of productivity and it has already better berth length utilization compared to the $2^{\text {nd }}$ group terminals, yet, still with significantly lower productivity per crane hour (-30\%).

- Koper terminal has very high productivity per berth length typical for CTs with a yearly throughput of over 1.25 million TEU and crane productivity per crane/hour similar to that of the $3^{\text {rd }}$ group of CTs, though it uses a lower number of berths (just 2).

\section{DISCUSSION}

The study shows that global CTs adapt berth infrastructure according to forecasted trends of mid-term throughput and that they follow the carriers' expectations. Berth utilization and productivity remain important variables in planning new installations in order to avoid excessive overcapacity. This is evident from berth length and the number of STS cranes per group of terminals. CTs build their infrastructure according to their market position; the more this position is global, the bigger are the ships that call at the terminal. Consequently, terminals are forced to build longer berths and install SPPC and MMC cranes.

The study of four EA CTs shows that the terminals took different development decisions in the last decade. The Port of Koper significantly increased its throughput through minimal investment in berth lengthening and presently uses the shortest berth length among the four CTs. According to the compared data of global CTs, this is a limiting element in further throughput increase, especially because two mother vessels (300 metres in length) cannot be served simultaneously. In addition, the STS crane productivity of 12.22 TEU movements per hour is very high and in case the terminal follows the strategy to supersede the yearly throughput of 1 to 1.2 million TEU, new investments in STS cranes will be necessary.

The CT in Trieste made significant changes in terminal structure and technology. By this the terminal is achieving significantly higher levels of productivity, but at the same time, compared to the $2^{\text {nd }}$ group terminals, it has margins for berth utilization and productivity increase. The difference is particularly evident in STS crane productivity. Installed capacity runs around 30\% below the level of the $2^{\text {nd }}$ group of terminals that have on average almost the same number of STS cranes. Consequently, the terminal has the infrastructure and suprastructure for higher yearly throughput typical for the $2^{\text {nd }}$ group terminals.
The CT at Rijeka remained in the first group of terminals. Terminal management has made important investments in the last ten years and the restructuring of the terminal is ongoing. With almost the same berth length as used by the Koper terminal, the terminal at Brajdica achieves three-times lower berth utilization. The number of STS cranes is in line with the average $1^{\text {st }}$ group terminals, but their productivity is about $20 \%$ lower. On this basis, the terminal has infrastructural and suprastructural overcapacity, but a good basis for the throughput increase in the coming years should the container flows use this terminal as the gateway for the Central European markets.

The fourth analysed CT at Bar did not make changes during the ten-year period. It remained at the minimal number of cranes and the same berth length that suggests significant overcapacity. The berth length is half the length of the CT at Koper and the terminal at Bar handles just $5 \%$ of the volume that is handled at Koper.

\section{CONCLUSION}

The study confirms the first hypothesis that global CTs follow container trade expansion by berth infrastructure and suprastructure modernisation. The selected 20 CTs installed new berth capacities to follow increases in container flows and trends where bigger ships are used by container carriers. The 20 analysed CTs installed 30\% more STS cranes and extended their berths by an additional $13 \%$ on average. At the same time berth modernisation is done with caution, in order to avoid significant overcapacity. Namely, overcapacity causes higher operational costs and significantly reduces financial results.

The second hypothesis, that EA CTs follow the global trend in berth modernisation and achieve higher subsystem's utilization and productivity, compared to the results a decade ago, has been also confirmed. The four terminals increased their throughput significantly over the global port throughput increase. The CT at Koper increased the throughput in 2016 by $285.8 \%$, Trieste by $103.7 \%$, Rijeka by $87.9 \%$ and Bar CT by $135.24 \%$ over the decade. Three CTs, except Bar, invested in berth infrastructure and suprastructure, but the throughput increased faster than berth modernisation. The four terminals achieved on average an increase of $160 \%$ on handled TEU per metre of berth length and $105 \%$ in moved TEU per STS crane and crane hour.

The third hypothesis, that EA CTs have possibilities for berth utilization and productivity improvement without further investments in berth infrastructure and suprastructure can be just partially confirmed. This is valid for the $\mathrm{CT}$ at Trieste, Rijeka and Bar, while the container terminal at Koper works at the upper limit, where further investments in berth extension and 
STS crane modernisation are needed to maintain the positive trend of the yearly throughput increase. The comparison of Trieste, Rijeka and especially Bar CT productivity results with the comparison model of CTs from the $1^{\text {st }}$ and $2^{\text {nd }}$ group of terminals shows a degree of berth overcapacity.

\section{ACKNOWLEDGMENTS}

The research is part of a bilateral project between Slovenia and Montenegro under the name "The Development of Intermodal Transport, Intermodal Nodes and Hinterland Network in the Eastern Adriatic Region".

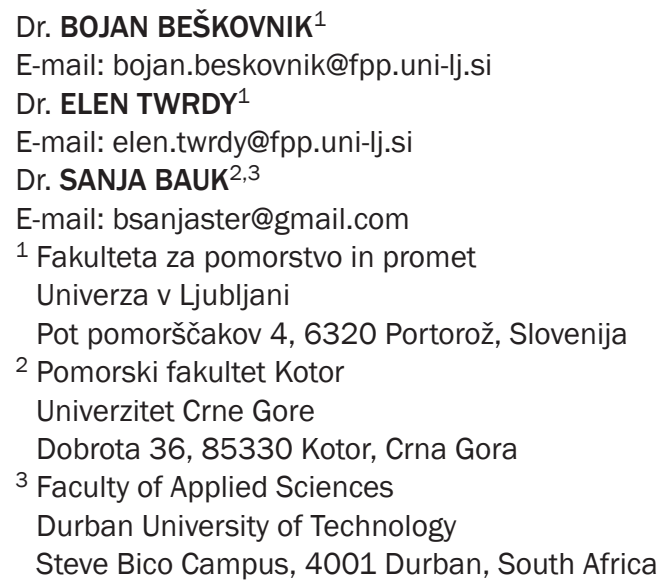

\section{RAZVOJ VIŠJE PRODUKTIVNOSTI NA PRIVEZU: PRIMERJAVA VZHODNO-JADRANSKIH KONTEJNERSKIH TERMINALOV}

\section{POVZETEK}

Članek analizira spremembe infrastrukture in suprastrukture na privezu globalnih kontejnerskih terminalov (KT) in štirih vzhodno-jadranskih pristanišč v zadnjem desetletju. Poudarek je na razumevanju, ali so KT v Kopru, Trstu, Reki in Baru dosegli višjo izkoriščenost in produktivnost na privezu po obalnem kontejnerskem dvigalu, in v kolikor je temu tako, kako je njihov razvoj skladen s svetovnim trendom produktivnosti na privezih KT. Kot prvi korak primerjave dosežene produktivnosti se uporablja primerjalni model dvajsetih izbranih globalnih KT. Študija je pokazala, da so štiri vzhodno-jadranska pristanišča sprejemala različne odločitve, vendar z enakimi cilji kot odziv na povečan pretok kontejnerjev preko jadranske transportne poti. Njihov glavni cilj je bil povišati produktivnost na privezih, ob nadzoru morebitne presežne zmogljivosti podsistema. Izvedene analize izkazujejo, da koprsko pristanišče obratuje na zgornji meji podsistema, medtem ko KT v Trstu, na Reki in v Baru delujejo z določeno stopnjo presežne zmogljivosti, tako infrastrukture kot tudi suprastrukture priveza.

\section{KLJUČNE BESEDE}

kontejnerski terminal; privez; infrastruktura; produktivnost; vzhodni Jadran;

\section{REFERENCES}

[1] Song L, Cherrett T, Guana W. Study on berth planning problem in a container seaport: Using an integrated programming approach. Computers \& Industrial Engineering. 2012;62(1): 119-128.

[2] Drewry Maritime Research. Container Market Annual Review and Forecast 2017/18. London, UK: Drewry Shipping Consultants Limited; 2017.

[3] ISL Institute of Shipping Economics and Logistics. Shipping Statistics and Market Review 2017. Bremen, DE: ISL Limited; 2017.

[4] Twrdy E, Batista M. Competition between container ports in the northern Adriatic. International Journal for Traffic and Transport Engineering. 2014;4(4): 363-371.

[5] Sys C, Blauwens G, Omey E, Van De Voorde E, Witlox F. In Search of the Link between Ship Size and Operations. Transportation Planning and Technology. 2008;31(4): 435-463.

[6] Kim K-H, Lee H. Container Terminal Operation: Current Trends and Future Challenges. In: Lee CY, Meng Q. (eds.) Handbook of Ocean Container Transport Logistics. Cham, CH: Springer International Publishing; 2015.

[7] Ho M-W, Ho K-H. Risk Management in Large Physical Infrastructure Investments: The Context of Seaport Infrastructure Development and Investment. Maritime Economics \& Logistics. 2006;8(2): 140-168.

[8] Koh Y-K. Optimal investment priority in container port development. Maritime Policy \& Management. 2001;28(2): 109-123.

[9] Novaes A-N, Scholz-Reiter B, Durski Silva V-M, Rosa H. Long-term planning of a container terminal under demand uncertainty and economies of scale. Pesquisa Operacional. 2012;31(1).

[10] Nishimura E, Imai A, Papadimitriou S. Berth allocation planning in the public berth system by genetic algorithms. European Journal of Operational Research. 2001;131(2): 282-292.

[11] Zhou P, Kang H-G. Study on Berth and Quay-crane Allocation under Stochastic Environments in Container Terminal. Systems Engineering - Theory \& Practice. 2008;28(1): 161-169.

[12] Imai A, Nishimura E, Hattori M, Papadimitrioud S. Berth allocation at indented berths for mega-containerships. European Journal of Operational Research. 2007;179(2): 579-593.

[13] Vacca I, Salani M, Bierlaire M. An Exact Algorithm for the Integrated Planning of Berth Allocation and Quay Crane Assignment. Transportation Science. 2013;47(2): 148-161.

[14] Bierwirth C, Meiselb F. A follow-up survey of berth allocation and quay crane scheduling problems in container terminals. European Journal of Operational Research. 2015;244(3): 675-689.

[15] Li Y, Zhu D, Wang Y. The optimization of utilization of container terminal, berth - the case of $X$ container terminal Ltd (XCT). BioTechnology: An Indian Journal. 2014;10(18): 10530-10536.

[16] Stojaković M, Twrdy E. A decision support tool for container terminal optimization within the berth subsystem. Transport. 2016;31(1): 29-40.

[17] Bassan S. Evaluating seaport operation and capacity 
analysis-preliminary methodology. Maritime Policy \& Management. 2007;34(1): 3-19.

[18] Luka Koper. Annual report for 2006. 2007. Available at: https://www.luka-kp.si/eng/annual-reports

[19] Trieste Marine Terminal. Annual statistics. 2017. Available at: http://www.trieste-marine-terminal.com/it/ statistiche

[20] Dundović Č, Hlača B. New concept of the container terminal in the Port of Rijeka. Scientific Journal of Maritime Research. 2007;21(2): 51-68.

[21] Luka Koper. Annual report for 2016. 2017. Available at: https://www.luka-kp.si/eng/annual-reports

[22] Port of Rijeka. Financial report for 2016. 2017. Available at: http://www.lukarijeka.hr/_Data/Files/ 196_2017022813108829/Godi\%C5\%A1nji\%20 fin.\%20izvj.2016.-nerevid.nekosolid.pdf 